УДК 004.008+371.378

(C) Овчар Н.В., 2021 p.

http://orcid.org/0000-0003-1602-3840

DOI: $10.34142 / 23128046.2021 .51 .12$

H. B. Oвчар

\title{
ОСОБЛИВОСТІ ПІДГОТОВКИ МАЙБУТНІХ УЧИТЕЛІВ ДО ВИКОРИСТАННЯ ІНТЕРАКТИВНОЇ ДОШКИ У НАВЧАЛЬНОМУ ПРОЦЕСІ ПОЧАТКОВОЇ ШКОЛИ
}

Стрімкий процес інформатизації суспільства вимагає від учителя вміння швидко орієнтуватися у потоці інформації, вибирати найцінніше та доносити учням. Також ие стосується і вміння використовувати сучасні засоби навчання, наприклад, інтерактивну дошку (ІД). Для найкращого результату педагогу необхідно вміти із нею праџювати. Це потребує правильної підготовки майбутніх учителів ще в процесі навчання у $3 В О$.

Інтерактивна дошка виступає мультимедійним засобом навчання (мультимедіа). Вона поєднує в собі можливості звичайної дошки та комп'ютера. Ї̈ використання у початковій школі сприяє кращому засвоєнню навчального матеріалу, оскільки у дітей даного віку переважає наочно-образне мислення.

Для ефективного навчання майбутніх вчителів початкової школи використовувати інтерактивну дошку, варто звернути увагу на певні особливості. Наприклад, уміння грамотно використовувати переваги ІД на уроках, знати ії можливості; створювати навчальний продукт, ще відповідає психологічним вимогам до дітей певного віку; готовність самого вчителя працювати й удосконалювати навички роботи з таким засобом та інше.

Важливо, щоб майбутні вчителі отримали необхідний обсяг теоретичних знань та практичних навичок. Вміле використання мультимедіа на уроках, дозволяє гармонійно поєднувати різні види інформаиії. Подавати ї̈ у максимально простому та зрозумілому для молодших школярів форматі.

Підготовка майбутніх учителів початкових класів, на нашу думку, має організовуватися таким чином, щуоб максимально розвивати творчі вміння як тих хто навчається, так $і$ тих хто навчає. Педагог - багатостороння особистість, що зобов'язана йти у ногу з часом.

Застосування в навчальному прочесі інтерактивної дошки вимагає знань про специфіку роботи з мультимедіа. Зокрема, про технічні характеристики, елементи програмування, знання програмного забезпечення та вміння ним користуватися, вміння оперувати інформачією, дотримання санітарногігієнічних норм, психологічних особливостей при роботі з дітьми тощо.

Тому, вважаємо, що ефективне використання інтерактивної дошки на уроках у початковій школі залежить від рівня підготовленості майбутнього учителя до такої роботи. 
Ключові слова: інтерактивна дошка, мультимедіа, учитель, молодші школярі.

Ovchar N. V. The specificity of future teachers' training on the use of smart boards in educational process of primary schools. Rapid process of informatization of society requires from teachers to gain the ability to orientate in the flow of information, to choose the most valuable data among that flow, and to get it out to learners. As well it relates to the ability to use contemporary means of education including smart boards (SB). Toachieve better results a teacher should know how to work with it. This ability requires the correct training of future teachers starting from their education in Higher Educational Institutions.

Smart board is represented as a kind of multimedia education. Both a simple board and a computer can be combined in it. The use of smart board in primary school can lead to higher level of education al material acquiring because children of this age mostly have visual thinking.

There is a need to pay attention to definite peculiarities to make training son the use of smart board by future teachers at primary school more effective. For example, the sepeculiarities include competentuse of SB benefits throughout the classes and knowledge concerning its functions. Moreover, teachers should know how to develop the educational product which will comply with psychological requirements of children of certain age, and they should be ready to work and improve their personal skills concerning the work with such device and others.

It is important, that future teachers got the necessary volume of theoretical knowledge and practical skills. The able use is multimedia on lessons, allows harmoniously to combine the different types of information. To give it in a maximally simple and clear for junior schoolchildren format.

Preparation of future teachers of initial classes, to our opinion, must get organized thus, maximally to develop creative abilities both those who studies and those who teaches. A teacher is multilateral personality that is under an obligation to go to the leg in course of time.

Application in the educational process of interactive board requires knowledge about the specific of work from multimedia. In particular about technical descriptions, elements of programming, knowledge of software and ability to use them, ability to operate information, observance of sanitary and hygienic norms, psychological features in-process with children etc.

That is why it is possible to say that effective use of smart boards throughout the classes of primary school depends on the level of future teachers' trainings on this kind of working activity.

Keywords: interactive whiteboard, multimedia, teacher, younger schoolchildren.

Вступ. Становлення сучасної української держави вимагає підвищення ролі і статусу професії вчителя в суспільстві. Вчитель як представник суспільства разом із батьками відповідає за кожного вихованця. Саме працівники 
педагогічної галузі повинні втілити в життя основні принципи організації освіти в Українській державі, як-от: надання рівного доступу до освіти всім без винятку, виключаючи дискримінації за будь-якими ознаками; організація освіти на наукових засадах; варіативність освіти; тісний зв'язок іiі iз світовою i національною історією, культурою, традиціями; академічна доброчесність; побудова системи освіти на гуманістичних та демократичних засадах; єдність процесів навчання, виховання і розвитку; патріотичне виховання, прищеплення поваги до культурних цінностей рідного народу, його історико-культурної спадщини та традицій; різнобічність надання інформації стосовно політичних, світоглядних і релігійних питань; виховання культури здорового способу життя, дбайливого ставлення до довкілля й екології й інше. (Zakon Ukrainy «Pro osvitu». Stattia 6, 2021). Для реалізації вищезазначеного, учителю знадобляться не лише традиційні методи роботи, а й додаткові технології. Зокрема, мультимедійні, частиною яких і виступає інтерактивна дошка.

3'ясовуючи умови і особливості інформатизації початкової школи, О. Чупріна провела анкетування серед вчителів початкових класів. Зміст питань був зорієнтований на визначення готовності вчителів початкових класів використовувати засоби мультимедіа на уроках. Результати проведеного анкетування засвідчили, що серед вчителів 97 \% опитуваних мають персональні комп'ютери, натомість лише 20 \% 3 них використовують їх на уроках і $30 \%$ вважають, що засоби мультимедіа не полегшують підготовку до уроків; 15 \% висловлюються проти їх використання на уроці, схиляючись до традиційних, «перевірених» засобів (Chuprina, 2014).

Результати діагностування засвідчили, що наявність домашнього комп’ютера ще не означає здатності вчителя використовувати цей засіб для оптимізації ефективного процесу навчання в початкових класах, не говорячи навіть про інтерактивну дошку. Це пояснюється недостатньою обізнаністю значної кількості вчителів з методикою й особливостями застосування мультимедіа на уроках у початковій школі.

Таким чином, ми розуміємо, що дослідження питання впровадження та використання інтерактивної дошки, як елемента мультимедійного навчання, $\epsilon$ актуальним. Воно вимагає знання певних особливостей при підготовці майбутніх учителів початкових класів до роботи з новітніми технологіями.

Мета та завдання. Мета cmammi полягає у визначенні особливостей підготовки майбутніх учителів до використання інтерактивної дошки у навчальному процесі початкової школи.

Методи дослідження. У процесі наукового пошуку використано переважно загальнонаукові методи (аналіз, синтез, систематизація, зіставлення, узагальнення, порівняння) з метою з'ясування суті проблеми, яка вивчається, 
3'ясування особливостей підготовки майбутніх учителів до використання інтерактивної дошки у навчальному процесі початкової школи.

Результати. Необхідність придбання уміння використовувати засоби мультимедіа майбутніми педагогами підкріплює ряд нормативних актів України: Розпорядження від 15 травня 2013 р. №386 «Про схвалення Стратегії розвитку інформаційного суспільства в Україні» (Rozporiadzhennia vid 15 travnia 2013. №386 «Pro skhvalennia Stratehii rozvytku informatsiinoho suspilstva v Ukraini», 2013), Указ «Про національну стратегію розвитку освіти в Україні на період до 2021 p.» (Ukaz «Pro natsionalnu stratehiiu rozvytku osvity v Ukraini na period do 2021», 2013), Рішення колегії МОН України №10 від 27.10.2016 «Нова українська школа. Концептуальні засади реформування середньої школи» (Rishennia kolehii MON Ukrainy №10 vid 27.10.2016 «Nova ukrainska shkola. Kontseptualni zasady reformuvannia serednoi shkoly», 2016).

Педагогу, який працює в сучасних умовах без використання сучасних педагогічних технологій загалом та мультимедійних засобів зокрема складно реалізувати індивідуальні траєкторії студентів із високим рівнем ефективності. Професіоналізації психологічної та педагогічної підготовки майбутнього вчителя початкових класів присвячені праці Н. Бібік, Н. Кузьміної, Н. Ничкало, О. Савченко, Г. Тарасенко, Л. Хомич, І. Шапошнікової та ін.

Аспект підготовки майбутніх учителів початкових класів до створення і використання комп'ютерної наочності розкрито у дослідженнях С. Гунько, М. Жалдак, О. Співаковський, Ф. Ривкінд, О. Чайковська, В. Шакотько, О. Шиман та інших (Prokopenko, 2008; Riabukha, 2010).

Ми погоджуємося із твердженням А. Лампіга, що мультимедіа - це окремий вид комп'ютерної технології, який об’єднує в собі як традиційну статичну візуальну інформацію (текст, графіку), так і динамічну - мовлення, музика, відеофрагменти, анімація (Lampiha, n. d.).

На нашу думку, твердження $Є$. Маркової, що до найбільш відомих та часто вживаних мультимедійних навчальних матеріалів, є досить влучним. Сюди належать: електронні підручники, навчальні посібники, комп'ютерні задачники, самоучителі, навчальні презентації, гіпертекстові інформаційно-довідкові системи (архіви, каталоги, довідники, енциклопедії, атласи, тестові та моделювальні програми, програми-тренажери, освітні програми з інтерактивними та ігровими елементами), мета яких - викликати пізнавальний інтерес, бажання опановувати навчальний матеріал та отримувати емоційне задоволення від навчання, саморозвитку та професійного вдосконалення (Markova, 2013). До цього списку можна додати і мультимедійний проектор, інтерактивну та віртуальну дошки. 
Перехід до нових комп'ютерно-орієнтованих технологій навчання, створення умов для їх розробки, апробації та використання, раціональне поєднання нових інформаційних технологій навчання 3 традиційними це складна педагогічна задача, яка потребує вирішення цілого комплексу психолого-педагогічних, організаційних, навчально-методичних, матеріальнотехнічних та інших проблем. Основними серед цих проблем М. Жалдак називає:

- $\quad$ розробку науково-методичного забезпечення для вирішення завдань інформатизації навчально-виховного процесу;

- $\quad$ підготовку педагогічних кадрів до використання у навчальному процесі засобів сучасних інформаційно-комунікаційних технологій;

- $\quad$ підготовку учнів та студентів до використання сучасних засобів навчально-пізнавальної діяльності;

- низьку ефективність використання матеріально-технічного та науково-методичного забезпечення навчальних закладів у зв'язку 3 їх застарілою базою;

- $\quad$ розробку методик використання сучасних інформаційних технологій навчання для підтримки більшості навчальних предметів (Zhaldak, 2004).

А. Коломієць вважає, що використання мультимедійних засобів навчання передбачає поєднання всіх аспектів їх розгляду (Kolomiiets, 2008):

1. Технічного - як конкретного мультимедійного технічного пристрою (діяльність користувача спрямована на обслуговування).

2. Семантичного - як інформації певного змісту, дизайну, інтерфейсу навчального мультимедійного засобу (діяльність спрямована на розуміння).

3. Прагматичного - як комунікації, обміну способами діяльності, поширення знань за рахунок завантаження, передавання файлів, пошуку, обміну даними (діяльність акцентована на застосуванні).

Науковець В. Чичук зазначає, що методична підготовка майбутніх учителів початкової школи з використанням мультимедійних засобів навчання охоплює такі етапи (Chychuk, 2011):

- визначення доцільності застосування мультимедійних засобів навчання;

- ознайомлення із змістом мультимедійних засобів навчання;

- визначення типу і структури уроку;

- $\quad$ визначення місця мультимедійного продукту в структурі уроку;

- $\quad$ самоперевірка студентом підготовки до уроку.

Даний алгоритм можна застосувати i до використання на уроках інтерактивної дошки. 
Підготовка майбутніх учителів початкової школи 3 використанням мультимедійних засобів виконує функції:

- $\quad$ навчальну допомагає отримувати студентам необхідну інформацію 3 певної дисципліни;

- $\quad$ виховну - виховувати самостійність при отриманні нових знать;

- $\quad$ розвивальну - розвивати образне творче мислення, набувати вміння правильно використовувати отриману інформацію.

В. Імбер визначає, що оволодіння майбутнім вчителем початкових класів необхідними навичками та знаннями при роботі з мультимедіа, включає наступні компоненти (Imber, 2005):

1) навчальний (уміння роботи 3 програмою Microsoft PowerPoint та іншими);

2) методичний (вироблення власної методики проведення уроків iз використанням можливостей мультимедійних засобів навчання);

3) професійний (залучення до підготовка осіб, що розуміються на використанні мультимедійних технологій).

Важливо розуміти, що основні можливості засобів мультимедіа, зокрема інтерактивної дошки в навчанні визначаються наочно-пізнавальним та наочнодидактичним методами. Це дає змогу урізноманітнити навчальний процес, зробити його більш цікавим та привабливим для молодших школярів.

Під час організації підготовки майбутніх учителів початкової школи до застосування мультимедійних засобів навчання (зокрема, й через використання інтерактивної дошки) у майбутній професійній діяльності важливо враховувати такі закономірності (Ponomarova, 2013):

- $\quad$ створення таких умов, що сприяють активній діяльності, розвитку мимовільної пам'яті, емоційної сфери, формуванню нових яскравих вражень (М. Скаткін);

- $\quad$ створення обставин, що сприяють формуванню цінностей, спільних для здобувачів, які допоможуть формувати мікрогрупи, мікроколективи, що легко взаємодіятимуть між собою (В. Оконь);

- створення таких умов, що спонукають до навчання, викликаючи постійне бажання щодо отримання знань (І. Харламов);

- $\quad$ викладач бере на себе головну роль у процесі забезпечення повноцінного засвоєння знань, умінь і навичок, розвитку розумових сил $\mathrm{i}$ творчих здібностей (В. Сластьонін).

Виділяють такі особливості впровадження мультимедійних засобів навчання у підготовку майбутніх учителів початкових класів (Huzii, 2004; Puhlii, 2013; Sikorskyi, 2004): 
• $\quad$ при підготовці до уроку з використанням мультимедійних засобів варто дотримуватися відповідних етапів;

- $\quad$ у діяльності спиратися на основні функцій навчального процесу;

- спираючись на різні аспекти (психологічний, педагогічний, методичний та організаційний), впроваджувати мультимедійні навчальні комплекси у практику під контролем викладача;

- психологічна готовність та вмотиваність майбутніх учителів до створення та використання мультимедіа;

- $\quad$ врахування особливостей розвитку психічних процесів (сприймання, уваги, мислення) молодших школярів під час використання мультимедіа;

- д добір відповідних методів і форм застосування мультимедійних засобів.

Дані особливості стосуються й інтерактивної дошки як елемента мультимедійного навчання.

У статті наукового журналу «Інформаційні технології в освіті», Н. Грицай визначає такі переваги мультимедійних засобів навчання при підготовці вчителя до уроку (Hrytsai, 2012):

- можливість залучення майже всіх органів чуття, поєднання друкованого тексту, графічного зображення, рухомого відео, статичних фотографій та аудіо запису;

- скорочення часу навчання, зростання рівня запам’ятовування;

- можливість сортування інформації;

- доступність інформації, робота з нетрадиційними джерелами, індивідуалізація навчального процесу за змістом, обсягом і темпами засвоєння навчального матеріалу;

- поглиблення міжпредметних зв’язків;

- $\quad$ автоматизація процесів контролю та корекції результатів навчальної діяльності;

- підвищення об’ єктивності оцінювання знань;

- $\quad$ скорочення часу на написання записів на дошці;

- $\quad$ активізація уваги учнів;

- можливість поєднання логічного й образного способів засвоєння інформації, що робить процес навчання більш насиченим та цікавим;

- активізація пізнавальної діяльності;

- відсутність потреби у роздруковуванні великої кількості ілюстративного матеріалу;

- забезпечення інтерактивності в навчальному процесі; 
- більша самостійність та рівень взаємодії із вчителем та дитячим колективом;

- забезпечення зворотного зв’язку;

- діалогізація навчального процесу;

- посилення мотивації навчання;

- максимальна адаптація процесу навчання до індивідуальних особливостей школярів (Nikolaienko, 2018).

На нашу думку, усе вказане вище характеризує й інтерактивну дошку. Вона надає змогу вчителю на якісно новому рівні організовувати процеси пошуку та поширення навчальної інформації. Сучасний педагог повинен володіти низкою компетентностей, зазначених у нормативних документах, що стосуються Нової української школи. Висока загальна та педагогічна культура того, хто навчає - це ключ до всебічного гармонійного розвитку того, хто навчається.

Зважаючи на стрімкий розвиток впровадження інформаційнокомунікаційних технологій в освітній процес, ми все ж погоджуємося із твердженням В. Барановської, що сучасний учитель початкових класів повинен не лише володіти основними прийомами роботи в мережі Інтернет, а й розуміти, як працювати із інформацією та адаптованими навчальними програмами 3 глобальної мережі. Повинен мати знання про ресурси, які сприяють педагогічному розвитку, уміння орієнтуватися у веб-документах, організовувати за допомогою електронної пошти зв’язок зі своїми колегами (Baranovska, 2011). Враховуючи сучасний розвиток інформаційних технологій, додамо до цього переліку ще й знання про організацію та роботу на навчальних платформах, таких як GoogleMeet, Classroom тощо.

Від учителя початкових класів, окрім загальних інформаційних умінь, вимагаються ще й уміння інтегрувати міжпредметні відомості, створювати якісно новий власний навчальний матеріал, поєднувати знання з різних галузей. На думку А. Коломієць, цьому сприяють заняття з використанням мережі Інтернет, у процесі яких студенти оволодівають методикою інформаційного самообслуговування, раціональними прийомами пошуку, аналізу й систематизації відомостей, навичками використання сучасних інформаційних технологій і мистецтвом формулювання суті пошукових запитів (Kolomiiets, 2007). Саме це і виступає наглядним прикладом реалізації вимог професійного стандарту щодо застосування сучасних змісту освіти, методик і технологій.

О. Нікулочкіна стверджує, що структура готовності вчителів початкових класів щодо використання мультимедіа в своїй професійній діяльності включає: 
- $\quad$ мотиваційний компонент, котрий полягає у бажанні ставити цілі, мати сформовану мотивацію саморозвитку та інтерес до використання інформаційних технологій у освітньому процесі початкової школи, потребу в самовдосконаленні, перелік професійно важливих якостей (працездатність, креативність, відповідальність, цілеспрямованість, здатність до рефлексії, наполегливість);

- $\quad$ функціональний компонент, який включає уміння використовувати засоби сучасних інформаційних технологій, апаратні та програмні засоби, ефективно використовувати технічні засоби навчання, засоби наочності (графіки, діаграми, схеми тощо) (Nikulochkina, 2012).

Додамо, що, на нашу думку, функціональний компонент можна конкретизувати ще й умінням працювати з інтерактивною дошкою.

Робота з нею надає такі переваги:

- $\quad$ режим білої дошки (характеризується не лише можливістю робити записи, але й зберігати їх та використовувати у подальшій роботі);

- демонстраційний екран (робота 3 презентаціями, спеціальними навчальними програмами, можливість виділити ключові елементи);

- $\quad$ аудіовізуальні можливості;

- підвищення інтересу до уроку чи заняття шляхом збільшення візуального матеріалу;

- $\quad$ можливість редагування матеріалу безпосередньо в процесі його використання.

Не зважаючи на низку переваг від використання мультимедіа, існують $\mathrm{i}$ ризики. Зокрема, вони стосуються роботи в мережі Інтернет. При пошуку та підготовці матеріалів для використання на уроках, майбутні вчителі можуть зустріти такі труднощі: нецензурні тексти, реклама непристойного характеру, віруси, спам тощо. Не варто забувати й про академічну доброчесність. Саме тому розуміння особливостей роботи з даними засобами навчання, дасть можливість мінімізувати ризики не лише для майбутніх учителів, але й для молодших школярів (Dotsenko \& Vorozhbit-Horbatiuk, 2021).

Обговорення. Проведене дослідження дозволяє стверджувати, що засоби мультимедіа, зокрема інтерактивна дошка, поступово впроваджуються в навчальний процес школи, адже їх можливості надзвичайно великі: сприяють розвитку критичного мислення, навичок роботи з великим обсягом інформації, стимулюють навчальний процес; дозволяють педагогу індивідуалізувати освітній процес, інтерактивно взаємодіяти з учнями та ін. 
Вони мають стати інструментом, за допомогою якого вчителі могли б точно визначати шляхи реалізації своїх психолого-педагогічних та методичних знань, розвиватися у професійній діяльності.

Висновки. Отже, в умовах широкого використання засобів сучасної комп'ютерної техніки в навчальному процесі значно зростають вимоги до професійної підготовки вчителя та його умінь використовувати мультимедіа в цілому та інтерактивну дошку зокрема під час професійної діяльності.

Спираючись на вищезазначене, можна виділити такі особливості підготовки майбутніх учителів до використання інтерактивної дошки у навчальному процесі початкової школи (що $\epsilon$ тісно пов'язаними iз мультимедійними засобами навчання), як-от:

- вирішення матеріально-технічних, навчально-методичних, психолого-педагогічних проблем;

- $\quad$ визначення етапності використання IT;

- оволодіння необхідними знаннями та навичками при роботі 3 мультимедіа;

- $\quad$ дотримання закономірностей;

- $\quad$ чітке розуміння переваг використання ІД та уміння правильно організувати роботу для їх реалізації.

\section{ЛІТЕРАТУРА:}

Закон України «Про освіту». Стаття 6, 2021. Режим доступу: https://zakon.rada.gov.ua/laws/show/2145-19\#Text

Чупріна О. Проблема готовності учителів початкових класів до застосування мультимедійних засобів на уроках рідної мови. Збірник наукових праиь, Ч. 2, 2014. С. 417-421.

Розпорядження від 15 травня 2013 р. №386 «Про схвалення Стратегії розвитку інформаційного суспільства в Україні», 2013. Режим доступу:

https://zakon.rada.gov.ua/laws/show/386-2013-\%D1\%80\#Text

Указ «Про національну стратегію розвитку освіти в Україні на період до 2021 р.», 2013. Режим доступу: https://zakon.rada.gov.ua/laws/show/344/2013\#Text

Рішення колегії МОН України №10 від 27.10.2016 «Нова українська школа. Концептуальні засади реформування середньої школи», 2016. Режим доступу:

https://base.kristti.com.ua/?p=1129

Прокопенко І. Ф. Сучасні педагогічні технології в підготовці вчителів : навч. посіб. Х. : Колегіум, 2008. 344 с.

Рябуха А. Ю. Упровадження мультимедійних технологій у навчальний процес як психологопедагогічна проблема. Сучасні інформаційні технологї та інноваційні методики навчання в підготовиі фахівиів: методологія, теорія, досвід, проблеми : зб. наук. пр., К.; Вінниця: ТОВ фірма «Планер», Вип. 25, 2010. С. 491-495.

Лампіга А. В. Мультимедійні засоби навчання. Режим доступу:

https://dorobok.edu.vn.ua/article/pdf/63.

Маркова С.С. Проблема підготовки майбутнього вчителя до впровадження засобів ІКТ у педагогічну діяльність, 2013. Режим доступу: http://scaspee.com/all-materials/45

Жалдак М. І. Комп'ютерно-орієнтовані засоби навчання математики, фізики, інформатики: посібник для вчителів, К. : НПУ імені Драгоманова, 2004. 182 с. 
Коломієць А. М. Теоретичні та методичні основи формування інформаційної культури майбутнього вчителя початкових класів. Автореф. дис. д. пед. н. : 13.00.04. Теорія і методика професійної освіти, К., 2008. 45 с.

Чичук В. Стан проблеми підготовки вчителя до використання мультимедійних технологій у початкових класах. Розвиток педагогічної науки в Украӥні і Польщі на початку XXI століття: зб. наук. пращь, Черкаси: Видавець Чабаненко Ю. А., 2011. С. 722-727.

Імбер В. I. Використання мультимедійних засобів у навчальному процесі. Сучасні інформаційні технологї та інновачійні методики навчання у підготовці фахівців: методологія, теорія, досвід, проблеми. Зб. наук. пр., Київ-Вінниця: ТОВ фірма «Планер», Вип. 7, 2005. С. 307-312.

Доценко Світлана, Ворожбіт-Горбатюк Вікторія, Собченко Тетяна. Онлайн-безпека учасників освітнього процесу в умовах дистанційного і змішаного навчання : навч.-метод. посіб., Х. : Вид-во «Ранок», 2021.

Пономарьова Г. Ф. Нові педагогічні технології. Навчальний посібник, Х., 2013. 280 с.

Гузій Н. В. Основи педагогічного професіоналізму : [навч. посіб.], К. : НПУ ім. М. П. Драгоманова, 2004. 156 с.

Пуглій В. В. Застосування мультимедійних технологій у процесі професійної підготовки майбутнього вчителя початкової школи. Scienceand Education a New Dimension : Pedagogy and Psychology, Budapest, Vol. I (7), 2013. C. 178-183.

Сікорський П. І. Комп’ютерні технології навчання: Сутність та особливості впровадження. Педагогіка і психологія, №4(45), 2004. С. 29-35.

Грицай Н. Б. Використання мультимедійних технологій у методичній підготовці майбутніх учителів біології. Інформаційні технології в освіті, № 13, 2012. С. 107-113.

Ніколаєнко М. С. Інтерактивна дошка: теорія і практика. Суми.: Ніко, 2018.

Барановська В. М. Організація фахової підготовки майбутнього вчителя початкової школи засобами сучасних інформаційних технологій. Педагогіка формування творчої особистості у вищій $і$ загальноосвітній школах : зб. наук. пр., Запоріжжя, Вип. 26, 2011. C. 24-30.

Коломієць А. М. Розвиток інформаційно-мережевої культури майбутнього вчителя початкових класів. Науковий часопис НПУ ім. М. П. Драгоманова. Серія № 2. Комп ’ютерно-орієнтовані системи навчання : зб. наук. пр., К. : НПУ, № 5 (12), 2007. C. 206-210.

Нікулочкіна О. В. Дослідження рівня готовності вчителів початкових класів до використання інформаційних технологій у професійній діяльності. Педагогіка формування творчої особистості у вищій $i$ загальноосвітній школах : зб. наук. пр., Запоріжжя, Вип. 22, 2012. C. 401-406.

\section{REFERENCES:}

Zakon Ukrainy «Pro osvitu». [Law of Ukraine "On Education"]. (2021). Stattia 6. Retrieved from: https://zakon.rada.gov.ua/laws/show/2145-19\#Text (in Ukrainian).

Chuprina, O. (2014). Problema hotovnosti uchyteliv pochatkovykh klasiv do zastosuvannia multymediinykh zasobiv na urokakh ridnoi movy. [The problem of readiness of elementary class teachers to the use of multimedia products in native language lessons]. Zbirnyk naukovykh prats, Ch. 2, 417-421, (in Ukrainian).

Rozporiadzhennia vid 15 travnia 2013 r. №386 «Pro skhvalennia Stratehii rozvytku informatsiinoho suspilstva v Ukraini». [Order from May 15, 2013 No. 386 "On Approval of the Strategy for Development of Information Society in Ukraine"]. (2013). Retrieved from: https://zakon.rada.gov.ua/laws/show/386-2013-\%D1\%80\#Text (in Ukrainian).

Ukaz «Pro natsionalnu stratehiiu rozvytku osvity v Ukraini na period do 2021 r.» [Decree "On the National Strategy for Education in Ukraine for a period up to 2021"]. (2013). Retrieved from: https://zakon.rada.gov.ua/laws/show/344/2013\#Text (in Ukrainian). 
Rishennia kolehii MON Ukrainy №10 vid 27.10.2016 «Nova ukrainska shkola. Kontseptualni zasady reformuvannia serednoi shkoly» [Decision of the Collegium of the Ministry of Education of Ukraine No. 10 dated October 27, 2016 "New Ukrainian School. Conceptual principles of secondary school reform "]. (2016). Retrieved from: https://base.kristti.com.ua/?p=1129 (in Ukrainian).

Prokopenko, I. F. (2008). Suchasni pedahohichni tekhnolohii v pidhotovtsi vchyteliv [Modern pedagogical technologies in preparation of teachers] : navch. posib. Kh. : Kolehium, $344 \mathrm{~s}$. (in Ukrainian).

Riabukha, A. Yu. (2010). Uprovadzhennia multymediinykh tekhnolohii u navchalnyi protses yak psykholoho-pedahohichna problema. [Implementation of multimedia technologies in the educational process as a psychological and pedagogical problem]. Suchasni informatsiini tekhnolohii ta innovatsiini metodyky navchannia $v$ pidhotovtsi fakhivtsiv: metodolohiia, teoriia, dosvid, problemy : zb. nauk. pr., K.; Vinnytsia: TOV firma «Planer», Vyp. 25, 491495 (in Ukrainian).

Lampiha, A. V. (n. d.). Multymediini zasoby navchannia. [Multimedia training tools]. Retrieved from: https://dorobok.edu.vn.ua/article/pdf/63 (in Ukrainian).

Markova, Ye.S. (2013). Problema pidhotovky maibutnoho vchytelia do vprovadzhennia zasobiv IKT $\mathrm{u}$ pedahohichnu diialnist. [The problem of preparing a future teacher to introduce ICTs in pedagogical activity]. Retrieved from: http://scaspee.com/all-materials/45 (in Ukrainian).

Zhaldak, M. I. (2004). Kompiuterno-oriientovani zasoby navchannia matematyky, fizyky, informatyky. [Computer-oriented Mathematics, Physics, Informatics]: posibnyk dlia vchyteliv, K. : NPU imeni Drahomanova, 182 s. (in Ukrainian).

Kolomiiets, A. M. (2008). Teoretychni ta metodychni osnovy formuvannia informatsiinoi kultury maibutnoho vchytelia pochatkovykh klasiv. [Theoretical and methodological bases of formation of information culture of the future teacher of elementary classes]. Avtoref. dys. d. ped. n. : 13.00.04. Teoriia i metodyka profesiinoi osvity, K., 45 s. (in Ukrainian).

Chychuk, V. (2011). Stan problemy pidhotovky vchytelia do vykorystannia multymediinykh tekhnolohii u pochatkovykh klasakh. [The state of the teacher's preparation problem to the use of multimedia technologies in elementary classes]. Rozvytok pedahohichnoi nauky $v$ Ukraini $i$ Polshchi na pochatku KhKhI stolittia: zb. nauk. Prats, Cherkasy: Vydavets Chabanenko Yu. A., 722-727 (in Ukrainian).

Imber, V. I. (2005). Vykorystannia multymediinykh zasobiv u navchalnomu protsesi. [Using multimedia in the learning process]. Suchasni informatsiini tekhnolohii ta innovatsiini metodyky navchannia u pidhotovtsi fakhivtsiv: metodolohiia, teoriia, dosvid, problemy. Zb. nauk. pr., Kyiv-Vinnytsia: TOV firma «Planer», Vypusk 7, 307-312 (in Ukrainian).

Dotsenko, Svitlana, Vorozhbit-Horbatiuk, Viktoriia \& Sobchenko, Tetiana (2021). Onlain-bezpeka uchasnykiv osvitnoho protsesu $\mathrm{v}$ umovakh dystantsiinoho i zmishanoho navchannia [Online security of the educational process participants in remote and mixed training] : navch.-metod. posib. Svitlana Dotsenko, Viktoriia Vorozhbit-Horbatiuk, Tetiana Sobchenko, Kharkiv : Vydvo «Ranok» (in Ukrainian).

Ponomarova, H. F. (2013). Novi pedahohichni tekhnolohii. [New Pedagogical Technologies]. Navchalnyi posibnyk, Kh., 280 s. (in Ukrainian).

Huzii, N. V. (2004). Osnovy pedahohichnoho profesionalizmu. [Fundamentals of pedagogical professionalism]: [navch. posib.], K. : NPU im. M. P. Drahomanova, 156 s. (in Ukrainian).

Puhlii, V. V. (2013). Zastosuvannia multymediinykh tekhnolohii u protsesi profesiinoi pidhotovky maibutnoho vchytelia pochatkovoi shkoly. [Application of multimedia technologies in the process of professional training of the elementary school teacher]. Science and Education a New Dimension : Pedagogy and Psychology, Budapest, Vol. I (7), 178-183 (in Ukrainian).

Sikorskyi, P. I. (2004). Kompiuterni tekhnolohii navchannia: Sutnist ta osoblyvosti vprovadzhennia. [Computer Technologies Training: Essence and Features of Implementation]. Pedahohika $i$ psykholohiia, №4(45), 29-35 (in Ukrainian). 
Hrytsai, N. B. (2012). Vykorystannia multymediinykh tekhnolohii u metodychnii pidhotovtsi maibutnikh uchyteliv biolohii. [Using multimedia technologies in methodical preparation of future biology teachers]. Informatsiini tekhnolohii v osviti, № 13, 107-113 (in Ukrainian).

Nikolaienko, M. S. (2018). Interaktyvna doshka: teoriia i praktyka. [Interactive Board: Theory and Practice]. Sumy: Niko (in Ukrainian).

Baranovska, V. M. (2011). Orhanizatsiia fakhovoi pidhotovky maibutnoho vchytelia pochatkovoi shkoly zasobamy suchasnykh informatsiinykh tekhnolohii. []. Pedahohika formuvannia tvorchoi osobystosti u vyshchii $i$ zahalnoosvitnii shkolakh: zb. nauk. pr., Zaporizhzhia, Vyp. 26, 24-30 (in Ukrainian).

Kolomiiets, A. M. (2007). Rozvytok informatsiino-merezhevoi kultury maibutnoho vchytelia pochatkovykh klasiv. [Development of information and network culture of the future teacher of elementary classes]. Naukovyi chasopys NPU im. M. P. Drahomanova. Seriia № 2. Kompiuterno-oriientovani systemy navchannia : zb. nauk. pr., K. : NPU, № 5 (12), 206-210 (in Ukrainian).

Nikulochkina, O. V. (2012). Doslidzhennia rivnia hotovnosti vchyteliv pochatkovykh klasiv do vykorystannia informatsiinykh tekhnolohii u profesiinii diialnosti. [Investigation of the level of readiness of elementary class teachers to the use of information technologies in professional activity]. Pedahohika formuvannia tvorchoi osobystosti u vyshchii i zahalnoosvitnii shkolakh : zb. nauk. pr., Zaporizhzhia, Vyp. 22, 401-406 (in Ukrainian).

\section{Інформація про автора:}

Овчар Наталія Володимирівна:

ORCID: 0000-0003-1602-3840

здобувач третього (освітньо-наукового) рівня вищої освіти кафедри освітології та інноваційної педагогіки, Харківський національний педагогічний університет імені Г. С. Сковороди, вул. Валентинівська, 2, Харків, Україна, 61166

e-mail: savyak199@gmail.com
Information about the author:

Ovchar Nataliia Volodymyrivna:

ORCID: 0000-0003-1602-3840

$\mathrm{PhD}$ candidate of the Department of Education and Innovative Pedagogy, H. S. Skovoroda Kharkiv National Pedagogical University, Street Valentynivska, 2, Kharkiv, Ukraine, 61166.

e-mail: savyak199@gmail.com

Цитуйте цю статтю як: Овчар Н. В. Особливості підготовки майбутніх учителів до використання інтерактивної дошки у навчальному процесі початкової школи. Теорія та методика навчання та виховання. 2021. № 51. C. 120-132. DOI: $10.34142 / 23128046.2021 .51 .12$

Дата надходження статті до редакції: 31.08.2021

Стаття прийнята до друку: 16.09.2021 